\title{
Evaluation of antioxidant potential and antibacterial activity of Calotropis gigantea and Vinca rosea using invitro model
}

\author{
D. Jayakumar, S. Jhancy Mary and R. Jaya Santhi \\ PG \& Research Dept. of Chemistry, Auxilium College, Vellore-632 006, TN, India. \\ shanthijaya@hotmail.com
}

\begin{abstract}
The different parts of Calotropis gigantea and Vinca rosea belonging to the families of Asclepiadaceae and Apocynaceae were studied for their antioxidant and antimicrobial activities against selected bacterial strains. From the results it was evident that the flower of Vinca rosea showed the highest antioxidant activity of $97.44 \%$ at $800 \mu \mathrm{g}$ which was higher than the standard L-ascorbic acid (94\%) and Calotropis gigantea showed the least. Calotropis gigantea exhibited highest inhibition zone of 14, 14 and $11 \mathrm{~mm}$ against Escherichia coli, Salmonella typhi and Shigella sonnei when compared to Vinca rosea. Hence, the present study supports the view, that these medicinal plants might be useful as antioxidant and antimicrobial agents.
\end{abstract}

Keywords: DPPH assay, antioxidant, antimicrobial, Vinca rosea, bacterial strains.

Introduction

Research in the chemistry of natural products has endless potential and is especially important in countries like India which has a rich biodiversity. In the recent years interest in the study of antioxidant activity of plant extracts and isolation from plants has grown due to the fact that the free radicals have been related to degenerative diseases (Willcox et al., 2004). Human cells are constantly exposed to reactive oxygen radicals generated by a number of biotic and abiotic factors such as irradiation, environmental factors, pollutants, stress or byproducts of metabolic processes. When the exposure overwhelms endogenous preventive systems, cells are exposed to potentially harmful load of oxidants, leading to various free radicals induced noxious effects. Free radical attacks biological molecules such as lipids, proteins, enzymes, DNA and RNA leading to cell or tissue injury associated with many diseases including ageing, atherosclerosis, heart diseases and carcinogenesis (Halliwell, 1994). Antioxidants are compounds which act as radical scavengers when added to the food products and prevent the radical chain reaction of oxidation, delay or inhibit the oxidation process and increase shelf life by retarding the processes of lipid peroxidation (Young et al., 2001). The ability of phenolic substances including flavonoids and phenolic acids acting as antioxidants has been reported (Liu et al., 2003). Tannins have been reported to have strong antioxidant activity (Cai et al., 2006). There is also growing interest both in industry and in scientific research in spices and medicinal herbs because of their antimicrobial and antioxidant activity (Eyob et al., 2008).

Vinca rosea has a variety of medicinal properties such as antibacterial (Carew et al., 1970), antifungal (Jaleel et al., 2007), antiviral (Fransworth et al., 1968), anticancer (Ram et al., 2001). Calotropis gigantea has been reported to possess a number of medicinal properties and is used in toothache, earache, sprain, anxiety, pain, epilepsy, mental disorder and also it possesses antidiarrheal, analgesic and CNS activity (Pathak \& Argal, 2007).

An extensive literature survey indicates antioxidant and antimicrobial activity in Calotropis gigantea and Vinca rosea. But only scanty information is available on such potential regarding the individual plant parts concerned (root, stem, leaf, flower \& seed). In the present research study, the experiment was carried out in triplicate so as to compare the antioxidant and antimicrobial activities of the different parts of the two selected Indian medicinal plants and the values were compared with that of the previous reports. The concentration dependency of the antioxidant and antimicrobial activities was also investigated.

\section{Materials and methods}

All chemicals and solvents were of analytical grade (Sigma-Aldrich). The bacterial strains were purchased from the Dept. of Molecular Biology, Christian Medical College and Hospital, Vellore, Tamil Nadu, India. Calotropis gigantea and Vinca rosea were identified by Ms. Isabella Roseline, Head, Dept. of Botany in Auxilium College campus and authenticated by a Taxonomist Mr. Babu, Cholayil, Chennai and the Vouchers of the plant specimen were deposited in the Dept. of Botany, Auxilium College with the code DRC_cg1 and DRC_vr1.

Different parts of the plant materials like root, stem, leaves, flower and seeds were shade dried, finely ground and were percolated in $100 \%$ methanol and filtered. The filtrate was evaporated at $40^{\circ} \mathrm{C}$ under reduced pressure by a rotary evaporator to give a semisolid residue of approximately $140 \mathrm{~g}$ each.

Cultures of seven human pathogenic bacteria belonging to 2 gram positive and 5 gram negative bacteria obtained from the Dept. of Microbiology, Christian Medical College (CMC), Vellore were used for
Research article

CIndian Society for Education and Environment (iSee)
"Efficacy of medicinal herbs from India" http://www.indjst.org
Jayakumar et al. Indian J.Sci.Technol. 
the invitro antibacterial assay. The bacterial strains Escherichia coli (ATCC25922), Klebsiella pneumonia (ATCC10031), Salmonella typhi (ATCC10749), Shigella sonnei (ATCC25931), Bacillus cereus (ATCC10987), Salmonella paratyphi (ATCC11511) and Staphylococcus auereus (ATCC25923) were chosen for the present study.

\section{Radical scavenging activity}

Experiments were carried out in triplicate, according to the method of Blois (1958) with the slight modification in Cakir et al. (2003). Briefly, $25 \mathrm{mg} / \mathrm{l}$ solution of DPPH radical (Aldrich) in methanol was prepared and then $2 \mathrm{ml}$ of this solution was mixed with different concentration $(400,600 \& 800 \mu \mathrm{g})$ of sample solution to achieve the final volume of $3 \mathrm{ml}$. After $30 \mathrm{~min}$ the absorbance was measured at $517 \mathrm{~nm}$. Decrease in the absorbance of the DPPH solution indicates an increase of the DPPH antioxidant activity. The antioxidant activity (AOA) was calculated using the equation:

$\mathrm{AOA}=\frac{\text { Ao- }-\mathrm{As}}{\mathrm{Ao}} \mathrm{Ao}$

Ao = DPPH solution without the sample

As $=\mathrm{DPPH}$ solution with the sample

\section{Antimicrobial activity}

Sterile nutrient broth was inoculated with freshly isolated bacterial culture and incubated for $24 \mathrm{~h}$ at $37^{\circ} \mathrm{C}$. The bacterial suspension was found to be approximately $10^{7}-10^{8}$ cells $/ \mathrm{ml}$. After the incubation period they were used as inoculum. About $0.1 \mathrm{ml}$ of the suspension containing $10^{8}$ colony forming unit $(\mathrm{CFU} / \mathrm{ml})$ of bacterial strains was taken to study by agar diffusion method (Estevinho et al., 2008). About $500 \mathrm{mg} / \mathrm{ml}$ of methanolic extracts of the plant materials with different concentrations like 5, 10, 12.5 and $25 \mathrm{mg}$ of sample were used and their zones of inhibitions were monitored after $24 \mathrm{~h}$ and the inhibition zone was compared with methanol which was a negative control.

\section{Statistical analysis}

The experiments were carried out in triplicate and the statistical software package (SPSS 12.0) was used for the statistical analysis and the results were given as a mean \pm standard deviation (SD). Regression analysis was carried out for the comparison of concentration dependency and one-way analysis of variance (ANOVA) was used for comparison of more than two means. A difference was considered statistically significant when $p$ $\leq 0.05$ (Sabir \& Rocha, 2008).

\section{Results and discussion}

Radical scavenging activity of Calotropis gigantea and Vinca rosea

The results of the antioxidant activity of Calotropis gigantea and Vinca rosea determined by DPPH assays at different concentrations are given in Table $1 \& 2$. From Table 1 it was evident that all parts of $C$. gigantea showed moderate antioxidant activity when compared with standard antioxidant L-ascorbic acid whose antioxidant activity at different concentrations like 400,600 and 800 $\mu \mathrm{g}$ were $84 \%, 88 \%$ and $94 \%$ and the antioxidant activity of L-ascorbic acid at $800 \mu \mathrm{L}$ (positive control) were in good agreement with the results of earlier workers (Taechowisan et al., 2009). The antioxidant activities followed the trend: stem $65.89 \%>$ flower $54.51 \%>$ root $44.29 \%>$ leaves $23.64 \%$. The radical scavenging activities of flower showed similar antioxidant activity at different concentrations. This clearly indicates that the antioxidant activity was highest at the $400 \mu \mathrm{g}$ and the increase in concentration showed least effect on the antioxidant activity. It was concentration independent as proved by regression analysis.

Table 1. Antioxidant potential of different parts of Calotropis gigantean.

\begin{tabular}{|c|c|c|c|c|}
\hline $\begin{array}{c}\text { Different } \\
\text { parts }\end{array}$ & $\begin{array}{c}\text { Conc. } \\
(\mu \mathrm{g})\end{array}$ & $\begin{array}{c}\text { Mean } \\
\text { absorbance } \\
\pm \text { SD }\end{array}$ & $\mathrm{R}^{2}$ & $\begin{array}{c}\text { Antioxidant } \\
\text { activity }(\%)\end{array}$ \\
\hline Leaves & 400 & $0.3895 \pm 0.0057$ & 0.955 & 15.14 \\
& 600 & $0.3627 \pm 0.0056$ & & 20.97 \\
& 800 & $0.3505 \pm 0.0049$ & & 23.64 \\
\hline \multirow{2}{*}{ Stem } & 400 & $0.2427 \pm 0.0065$ & 0.937 & 31.43 \\
& 600 & $0.2092 \pm 0.0069$ & & 40.89 \\
& 800 & $0.1207 \pm 0.0065$ & & 65.89 \\
\hline \multirow{3}{*}{ Root } & 400 & $0.3110 \pm 0.0092$ & 0.990 & 18.16 \\
& 600 & $0.2252 \pm 0.0074$ & & 30.90 \\
& 800 & $0.1025 \pm 0.0053$ & & 44.29 \\
\hline \multirow{3}{*}{ Flower } & 400 & $0.2622 \pm 0.0073$ & 0.997 & 51.25 \\
& 600 & $0.2526 \pm 0.0067$ & & 52.37 \\
& 800 & $0.2447 \pm 0.0056$ & & 54.51 \\
\hline
\end{tabular}

Table 2 shows the antioxidant activities of different parts of $V$. rosea at various concentrations. From the Table it was clear that all the parts of $V$. rosea showed the highest antioxidant activity and followed the trend flower (97.44\%) $>$ stem $(93.80)=$ root $(93.84)>$ leaves $(83.72)>$ seed (80.28) and the antioxidant activity of flower was higher

Table 2. Antioxidant potential of different parts of Vinca rosea.

\begin{tabular}{|c|c|c|c|c|}
\hline $\begin{array}{c}\text { Different } \\
\text { parts }\end{array}$ & $\begin{array}{c}\text { Conc. } \\
(\mu \mathrm{g})\end{array}$ & $\begin{array}{c}\text { Mean } \\
\text { absorbance } \\
\pm \text { SD }\end{array}$ & $\mathrm{R}^{2}$ & $\begin{array}{c}\text { Antioxidant } \\
\text { activity (\%) }\end{array}$ \\
\hline Leaves & 400 & $0.0652 \pm 0.0092$ & 0.372 & 82.36 \\
& 600 & $0.0790 \pm 0.0076$ & & 82.56 \\
& 800 & $0.0737 \pm 0.0083$ & & 83.72 \\
\hline Stem & 400 & $0.0520 \pm 0.0057$ & 0.967 & 86.87 \\
& 600 & $0.0427 \pm 0.0046$ & & 89.20 \\
& 800 & $0.0247 \pm 0.0069$ & & 93.75 \\
\hline \multirow{3}{*}{ Root } & 400 & $0.0322 \pm 0.0074$ & 0.797 & 93.15 \\
& 600 & $0.0292 \pm 0.0069$ & & 93.79 \\
& 800 & $0.0290 \pm 0.0076$ & & 93.84 \\
\hline \multirow{3}{*}{ Flower } & 400 & $0.1252 \pm 0.0079$ & 0.979 & 54.29 \\
& 600 & $0.0812 \pm 0.0067$ & & 70.35 \\
& 800 & $0.0070 \pm 0.0071$ & & 97.44 \\
\hline \multirow{2}{*}{ Seed } & 400 & $0.2240 \pm 0.0087$ & & 52.24 \\
& 600 & $0.1845 \pm 0.0066$ & 0.950 & 60.66 \\
& 800 & $0.0925 \pm 0.0083$ & & 80.28 \\
\hline
\end{tabular}

Research article

CIndian Society for Education and Environment (iSee)
"Efficacy of medicinal herbs from India" http://www.indjst.org
Jayakumar et al. Indian J.Sci.Technol. 
than L-ascorbic acid at $800 \mu \mathrm{g}$. This may be due to the presence of phenolic compounds and flavonoids as detected by photochemical analysis which were responsible for the antioxidant activity even at lower concentrations (Villano et al., 2007). The antioxidant activities of leaves, stem and root were independent of concentration which shows that it may contain phytochemicals that are responsible for antioxidant activities as it was evident from the Table 5. From the Table $1 \& 2$ it was also evident that good precision was observed which was evident from the standard deviation values.

Table 3. Antibacterial activity of Calotropis gigantean.

\begin{tabular}{|c|c|c|c|c|c|c|c|c|}
\hline $\begin{array}{c}\text { Plant } \\
\text { parts }\end{array}$ & $\begin{array}{c}\text { Conc. } \\
(\mathrm{mg})\end{array}$ & $\begin{array}{c}\text { B.c } \\
(\mathrm{mm})\end{array}$ & $\begin{array}{c}E . c \\
(\mathrm{~mm})\end{array}$ & $\begin{array}{c}K . p \\
(\mathrm{~mm})\end{array}$ & $\begin{array}{c}S . a \\
(\mathrm{~mm})\end{array}$ & $\begin{array}{c}S . S \\
(\mathrm{~mm})\end{array}$ & $\begin{array}{c}S . p \\
(\mathrm{~mm})\end{array}$ & $\begin{array}{c}S . t \\
(\mathrm{~mm})\end{array}$ \\
\hline \multirow{5}{*}{ Leaves } & 05.0 & - & - & - & - & - & - & - \\
& 10.0 & - & - & - & - & - & - & - \\
& 12.5 & - & - & - & - & - & - & - \\
& 25.0 & - & 8 & 9 & 8 & - & - & 6 \\
\hline \multirow{5}{*}{ Stem } & 05.0 & - & - & - & - & - & - & - \\
& 10.0 & - & - & - & - & - & - & - \\
& 12.5 & - & - & - & - & - & - & - \\
& 25.0 & - & - & 6 & - & - & - & - \\
\hline \multirow{5}{*}{ Root } & 05.0 & - & - & - & - & - & - & - \\
& 10.0 & - & - & - & - & - & - & - \\
& 12.5 & 6 & - & - & - & 6 & 6 & - \\
& 25.0 & 9 & - & - & - & 8 & 8 & - \\
\hline \multirow{5}{*}{ Flower } & 05.0 & - & - & - & - & - & - & - \\
& 10.0 & - & - & - & - & - & - & - \\
& 12.5 & 6 & 6 & - & - & - & - & 6 \\
& 25.0 & 9 & 14 & 6 & 6 & 11 & 9 & 14 \\
\hline
\end{tabular}

Bacillus cereus (B.c); Escherichia coli (E.c); Klebsiella pneumonia (K.p); Staphylococcus auereus (S.a); Shigella sonnei (S.s);

Salmonella paratyphi (S.p); Salmonella typhi (S.t)

Table 4. Antibacterial activity of Vinca rosea.

\begin{tabular}{|c|c|c|c|c|c|c|c|c|}
\hline $\begin{array}{c}\text { Plant } \\
\text { parts }\end{array}$ & $\begin{array}{c}\text { Conc. } \\
(\mathrm{mg})\end{array}$ & $\begin{array}{c}B . c \\
(\mathrm{~mm})\end{array}$ & $\begin{array}{c}E . c \\
(\mathrm{~mm})\end{array}$ & $\begin{array}{c}\text { K.p } \\
(\mathrm{mm})\end{array}$ & $\begin{array}{c}S . a \\
(\mathrm{~mm})\end{array}$ & $\begin{array}{c}S . S \\
(\mathrm{~mm})\end{array}$ & $\begin{array}{c}S . p \\
(\mathrm{~mm})\end{array}$ & $\begin{array}{c}S . t \\
(\mathrm{~mm})\end{array}$ \\
\hline \multirow{4}{*}{ Leaves } & 05.0 & - & - & - & - & - & - & - \\
& 10.0 & - & - & - & - & - & - & - \\
& 12.5 & - & - & 6 & - & - & 9 & - \\
& 25.0 & - & - & 8 & - & - & 11 & - \\
\hline \multirow{5}{*}{ stem } & 05.0 & - & - & - & - & - & - & - \\
& 10.0 & - & - & - & - & - & - & - \\
& 12.5 & - & - & - & - & - & 6 & - \\
& 25.0 & - & 6 & - & 7 & - & 10 & 6 \\
\hline \multirow{5}{*}{ Flower } & 05.0 & - & - & - & - & - & - & - \\
& 10.0 & - & - & - & - & - & - & - \\
& 12.5 & - & 8 & - & - & 6 & 6.5 & - \\
& 25.0 & - & 11 & 10 & 6 & 8 & 10 & 6 \\
\hline \multirow{5}{*}{ Root } & 05.0 & - & - & - & - & - & - & - \\
& 10.0 & - & - & - & - & - & - & - \\
& 12.5 & - & - & 6 & 6 & - & - & - \\
& 25.0 & - & 6 & 8 & 9 & 6 & 6 & 6 \\
\hline \multirow{5}{*}{ Seed } & 05.0 & - & - & - & - & - & - & - \\
& 10.0 & - & - & - & - & - & - & - \\
& 12.5 & - & - & - & - & - & - & - \\
& 25.0 & 6 & 6 & - & - & - & - & 6 \\
\hline
\end{tabular}

Bacillus cereus (B.C); Escherichia coli (E.c); Klebsiella pneumonia (K.p); Staphylococcus auereus (S.a); Shigella sonnei (S.s); Salmonella paratyphi (S.p); Salmonella typhi (S.t)
Vol. 3 No. 7 (July 2010)

ISSN: 0974- 6846
From the regression analysis it was clear that there was a good linearity between concentration and absorbance for all the parts of $C$. gigantea and $V$. rosea except the root and leaves of $V$. rosea whose $R^{2}$ value were 0.797 and 0.372 respectively. Hence, the root and leaves of $V$. rosea were concentration independent at experimental concentrations. The poor linearity in leaves of $V$. rosea $\left(R^{2}=0.372\right)$ may be due to the interfering plant pigments. One way analysis of variance (ANOVA) was used to test the level of significance between absorbance and concentration. The experiments were conducted in triplicate and the probability factor $(P)$ was $<0.05$ between different parts of $C$. gigantea and $V$. rosea and so it was considered as significant.

\section{Antibacterial activity}

In the present study, the methanolic extracts of various parts of $C$. gigantea and $V$. rosea were selected for antibacterial activity on seven different microorganisms- Escherichia coli (E.c), Klebsiella pneumonia (K.p), Salmonella typhi (S.t), Shigella sonnei (S.s), Bacillus cereus (B.C), Salmonella paratyphi (S.p) and Staphylococcus auereus (S.a). Depending on the measured values of the complete inhibition diameter in $\mathrm{mm}$, the antibacterial activity can be classified into the following types, such as $>12 \mathrm{~mm}$ zone of inhibition-high sensitivity, $9-12 \mathrm{~mm}$ zone of inhibition-moderate sensitivity, $6-9 \mathrm{~mm}$ zone of inhibition-less sensitivity and $<6 \mathrm{~mm}$ zone of inhibition-resistant (Uma Devi et al., 2007).

\section{Antibacterial activity of Calotropis gigantea.}

The antibacterial activities of various parts of C. gigantea for selected test bacterial strains at different concentrations were given in Table 3 . From the Table it was clear that, all the samples at different concentrations (5, 10, $12.5 \& 25 \mathrm{mg})$ gave different inhibition activities towards tested organisms when compared with the negative control methanol whose inhibition zone was 6 $\mathrm{mm}$. Among the different plant extracts, flower showed the highest antibacterial activity against Escherichia coli and Salmonella typhi with the net inhibition zone of $14 \mathrm{~mm}$ at $25 \mathrm{mg}$. Root exhibited moderate sensitivity against Shigella sonnei, Bacillus cereus and Salmonella paratyphi. The stem was bacterial resistant to all the selected bacterial strains.

\section{Antibacterial activity of Vinca rosea.}

Preliminary screening for antibacterial activities of different parts like leaves, stem, flower, root and seed of $V$. rosea against the seven selected bacterial strains at various concentrations are given in Table 4. The flower
Research article

CIndian Society for Education and Environment (iSee)
"Efficacy of medicinal herbs from India" http://www.indjst.org
Jayakumar et al. Indian J.Sci.Technol. 
Indian Journal of Science and Technology

Table 5. Phytochemical analysis of Calotropis gigantea \& Vinca rosea.

\begin{tabular}{|l|c|c|c|c|c|c|c|c|}
\hline \multirow{2}{*}{ Phytochemicals } & \multicolumn{6}{|c|}{ Calotropis gigantea } & \multicolumn{5}{c|}{ Vinca rosea } \\
\cline { 2 - 9 } & Leaves & Root & Stem & Flower & Leaves & Root & Stem & Flower \\
\hline $\begin{array}{l}\text { Phenolic } \\
\text { compounds }\end{array}$ & - & - & - & + & + & - & - & + \\
\hline Steroids & + & + & + & + & - & + & + & - \\
\hline Terpenoids & - & - & - & - & - & - & - & - \\
\hline Flavonoids & - & - & - & + & + & - & - & + \\
\hline Sugars & + & + & + & + & + & + & + & + \\
\hline Coumarin & - & - & - & - & + & + & + & + \\
\hline Quinone & - & - & - & + & + & - & + & + \\
\hline Tannins & - & - & - & - & + & - & - & - \\
\hline Saponin & + & + & + & + & + & + & + & + \\
\hline
\end{tabular}

exhibited different zone of inhibition for all tested bacterial strains- Escherichia coli, Klebsiella pneumonia, Staphylococcus auereus, Shigella sonnei, Salmonella paratyphi and Salmonella typhi except Bacillus cereus. Leaves and root showed moderate sensitivity against $K$. pneumonia and the other test organisms were least sensitive towards the different parts of $\mathrm{V}$. rosea.

The higher antioxidant and moderate antimicrobial activity may be due to the presence of phytochemicals like phenolic compounds, flavonoids, coumarin, quinones etc., as proved by the phytochemical analysis (Table 5).

\section{Conclusion}

The present study revealed that the all the parts of Vinca rosea showed better radical scavenging activity when compared to Calotropis gigantea. Within different parts of Calotropis gigantean, stem showed highest antioxidant activity at $800 \mu \mathrm{g}$ when compared to its leaves, roots and flower. The results of this study also revealed that the zone of inhibition was different for different parts of $C$. gigantea and $V$. rosea against different microorganisms tested. The highest inhibition zone of 14, 14 and $11 \mathrm{~mm}$ was exerted by Calotropis gigantea against Escherichia coli, Salmonella typhi and Shigella sonnei when compared to Vinca rosea. Hence, the present study supports the view that these medicinal plants might be useful as antioxidant and antimicrobial agents. Further research should be aimed on adapting suitable methods so that the active principles are isolated and at the same time its efficacy is preserved during extraction and concentration.

\section{Acknowledgements}

The authors are grateful to UGC, New Delhi for providing financial support to carry out this project and to the Dept. of Microbiology, Auxilium College for their support in the microbial studies.

\section{References}

1. Cai YZ, Sun M, Xing J, Luo Q and Corke H (2006) Structure-radical scavenging activity relationships of phenolic compounds from traditional Chinese medicinal plants. Life Sci. 78, 2872-2888.

2. Cakir A, Maci A, Yyldyrym A, Durub ME, Harmandar M and Kazaz V (2003) Isolation and characterization of

Research article

CIndian Society for Education and Environment (iSee) essential oil of korarimo. Afri. $J$. Biotechnol. 2592.

6. Fransworth NR, Svoboda GH and Blomster RN (1968) Antiviral activity of selected catharanthus alkaloids. J. Pharmacol. Sci. 57, 2174-2175.

7. Halliwell B (1994) Free radicals, antioxidants and human disease: curiosity, cause or consequence. Lancer. 344, 721-724.

8. Jaleel CA, Monivannan P and Sankar P (2007) Introduction of drought stress tolerance by ketoconazole in catharanthus roseus is mediated by enhanced antioxidant potential and secondary metabolite accumulation. Colloids Surfaces. B. Biointerfaces. 60, 201-206.

9. Liu YW, Han CH, Lee MH, Hsu FL and Hou WC (2003) Patatin, the tuber storage protein of potato (Solanum tuberosum L.), exhibits antioxidant activity invitro. J. Agric. Food. Chem. 51, 4389-4393.

10. Pathak AK and Argal A (2007) Analgesic activity of Calothropis gigantea flower. Fitoterapia. 78, 40-42.

11. Ram VJ and Kumarin S (2001) Natural products of plant origin as anticancer agents. Drug News Perspect, 8, 465482.

12. Sabir SM and Rocha JBT (2008) Antioxidant and hepatoprotective activity of aqueous extract of Solanum fastigiatum (false" Jurubebe") against paracetamolinduced liver demage in mice. J. Ethnopharmacol. 120, 226-232.

13. Taechowisan $T$, Chanaphat $N$, Wanbenjob $A$ and Shen $Y$ (2009) Cytoprotective activity of chemical constituents isolated from Streptomyces sp., Int. J. Biol. Chem. 3(1), 11-17.

14. Uma Devi $P$, Murugan $S$, Suja $S$, Selvi $S$, Chinnasamy $P$ and Vijayaanad E (2007) Antibacterial, invitro lipid per-oxidation and phytochemical observation on Achyranthes bidentata blume. Pak. J. Nutrition. 6(5), 447-451.

15. Villano D, Pachon MSF, Moya ML, Troncoso AM and Garcia Parrilla MC (2007) Radical scavenging ability of polyphenolic compounds towards DPPH free radical. Talanta. 71, 230-235.

16. Willcox JK, Ash SL and Catignani GL (2004) Antioxidant and prevention of chronic disease. Crit. Rev. Food Sci. Nutrition. 44, 275-295.

17. Young IS and Woodside JV (2001) Antioxidants in health and disease. J. Clinical Pathol. 54, 176-186.
"Efficacy of medicinal herbs from India" http://www.indjst.org
Jayakumar et al. Indian J.Sci.Technol. 